\title{
Margaret McCartney: The Care Quality Commission is not fit for purpose
}

\author{
(®) $(1) \Theta$ OPEN ACCESS
}

Margaret McCartney general practitioner, Glasgow

"GP surgeries: Is your doctor's surgery one of the 1 in 6 failing?" asked the Western Daily Press. "Best and worst GP surgeries revealed," claimed a local newspaper in London. ${ }^{2}$

These headlines were caused by the Care Quality Commission's (CQC) decision to publish "intelligent monitoring" data from general practices. England's independent health and social care regulator put out a press release quoting Norman Williams, past president of the Royal College of Surgeons, who had said: "It is absolutely right that patients are aware of the quality of the services that are provided so they can make choices about their care." ${ }^{3}$

But GPs I've spoken to are distressed about their surgeries' ratings, are dismayed at their interactions with the CQC, and are accelerating their own plans for retirement during a recruitment crisis. The CQC seems to have neglected the central tenet of good medical practice: do not assume that your intervention is doing more good than harm. And if the CQC is not looking for harms, how will they ever be counted?

The commission's public data dump considers 38 "indicators" classified according to "risk" or "elevated risk." It has three indicators that the CQC judges as showing "elevated risk" to place a practice into the highest risk category (of six). ${ }^{4}$ These indicators include the dementia diagnosis rate (surprising, given the uncertainty about its true prevalence and the widespread criticism about local schemes to pay GPs for making the diagnosis $)^{5}$ and reducing blood pressure to $150 / 90 \mathrm{~mm} \mathrm{Hg}$ (despite Cochrane finding no gain in mortality or morbidity with blood pressures below 159/99 $\mathrm{mm} \mathrm{Hg}$ in people without cardiovascular disease). ${ }^{6}$

One practice in the highest risk category had scored well on safe prescribing, on access to GPs, on GPs and nurses being good at involving patients in decisions, and on patients being satisfied with opening hours and getting through on the phone; but it had not filled in the requisite number of care plans for people with mental illness, had not recorded their alcohol consumption, and had not given flu vaccinations to "enough" patients. Describing this as a "high risk" practice is ludicrous.
Worse, the CQC has not related its risk categories to actual inspections, meaning that we have no idea about the false positive or false negative rate. How much work and effort have gone into ticking boxes for CQC inspections rather than towards direct patient care? The CQC is a failing organisation, incapable of translating the uncertainties in data to the public, and causing damage in its wake. And its lack of apology shows a lack of insight or understanding about its actions; it is not fit for purpose.

Competing interests: I have read and understood the BMJ policy on declaration of interests and declare the following interests: I'm an NHS GP partner, with income partly dependent on Quality and Outcomes Framework points. I'm a part time undergraduate tutor at the University of Glasgow. I've written a book and earned from broadcast and written freelance journalism. I'm an unpaid patron of Healthwatch. I make a monthly donation to Keep Our NHS Public. I'm a member of Medact. I'm occasionally paid for time, travel, and accommodation to give talks or have locum fees paid to allow me to give talks but never for any drug or public relations company. I was elected to the national council of the Royal College of General Practitioners in 2013.

Provenance and peer review: Commissioned; not externally peer reviewed.

1 Western Daily Press. GP surgeries: Is your doctor's surgery one of the 1 in 6 failing? 18 Nov 2014. www.westerndailypress.co.uk/GP-surgeries-doctors-surgery-1-6-failing/story24551080-detail/story.html.

Patient D. Best and worst GP surgeries revealed in Wanstead and Woodford. East London and West Essex Guardian 20 Nov 2014. www.guardian-series.co.uk/news/11612651. Best_and_worst_GP_surgeries_revealed/.

3 Care Quality Commission. Inspections of general practices based on best available data. 17 Nov 2014. www.cqc.org.uk/content/inspections-general-practices-based-best-availabledata.

4 Care Quality Commission. Intelligent monitoring: NHS GP practices-indicators and methodology. Nov 2014. www.cqc.org.uk/sites/default/files/20141113_GP_IM_Indicators_ and_Methodology_Guidance_Publication.pdf.

5 McCartney M. Dementiagate-how politicised pay diverts GPs from working for patients. BMJ 2014;349:g6446.

$6 \quad$ Dioa D, Wright JM, Cundiff DK Gueyffier F. Benefits of antihypertensive drugs for mild hypertension are unclear. Cochrane Summaries 14 Nov 2012. http://summaries.cochrane. org/CD006742/HTN_benefits-of-antihypertensive-drugs-for-mild-hypertension-are-unclear. 
This is an Open Access article distributed in accordance with the Creative Commons Attribution Non Commercial (CC BY-NC 4.0) license, which permits others to distribute, remix, adapt, build upon this work non-commercially, and license their derivative works on different terms, provided the original work is properly cited and the use is non-commercial. See: http://creativecommons.org/licenses/by-nc/4.0/. 